\title{
SOCIO-ECONOMIC IMPACTS OF ECER-HUMAN CAPITAL DEVELOPMENT PROGRAMMES IN EMPOWERING THE RURAL WOMEN OF MALAYSIA
}

\author{
Abdul Rahman Abdul Latip* \\ Universiti Malaysia Terengganu \\ Norfatiha Othman \\ Universiti Malaysia Terengganu \\ Osman Md Yusoff \\ Universiti Sains Malaysia
}

\begin{abstract}
The contribution and roles of women in the well-being of the family and nation building are fairly visible in Malaysia. However, a study by the World Bank discovered that married women in Malaysia in fact have the lowest participation in the workforce. In addressing this problem, the Malaysian East Coast Economic Region (ECER) policy has come up with various socio-economic programmes to overcome this challenge. This study aims to analyse the impacts of the human capital development initiatives on women in the rural ECER states of Kelantan, Terengganu, Pahang, and the district of Mersing in Johor. This study uses the quantitative method by administering a set of questionnaires to 147 women respondents across the ECER states. It also uses the qualitative approach involving in-depth interviews with ten key informants and a session of Focused-Group Discussion. It also included direct observation, as well as literary research. The outcome of this study finds improvement in the women's occupational involvement and their income. This study also discovers that rural women are naturally empowered by the programme.
\end{abstract}

Keywords: Socio-economic impacts; Human capital development programmes; Women's empowerment; East Coast Economic Region (ECER)

Received: 24 May 2019

Accepted: 19 September 2019

\section{INTRODUCTION}

In achieving a sustainable development, gender equality and women's empowerment are vital elements that should be considered by any countries. It is one of the eight goals outlined in Millennium Development Goals (MDGs) by United Nations. The contributions and roles of women in well-being of family and national development are fairly visible in Malaysia. However, a study by World Bank discovered that married women in Malaysia in both urban and rural areas

*Corresponding author: School of Business, Economic and Social Development, Universiti Malaysia Terengganu, 21030 Kuala Nerus, Terengganu, Malaysia: Tel: +0134556578; Email: rahmanlatip89@yahoo.com 
had the lowest participation rate in the workforce. One of the main reasons that women are not working is their need to take care of their family and children (The Star Online, 2018).

Therefore, East Coast Economic Region (ECER) under the human capital development division has implemented several human capital development programmes specially designed to overcome this challenge. The programmes like empower ECER, entrepreneur ECER, Suri@Home, Agropolitan Project and Terminal Jahitan Programme are the initiatives taken by ECER to enhance women's capability and contribute to women's empowerment in this region. It is essential to ensure that people in the local community especially women in rural areas are not left in socio-economic development.

ECER is one of five regional economic corridors established in Malaysia to facilitate the socioeconomic transformation of this region towards becoming a high income nation by 2020. It covers the states of Kelantan, Terengganu, Pahang, and the district of Mersing in Johor. The high impacts projects and human capital development programmes implemented to decrease the socio-economic inequalities, eliminate poverty and improve the income and wealth distribution sustainably. As of 2017, ECER managed to attract a total of RM 111.6 billion of committed private investment, provided 149, 400 job opportunities, and created about 31, 700 entrepreneurs or business opportunities within the region. The human capital programmes have been successful in transforming the lives of the target groups, especially the low-income households, youths and the Orang Asli. Apart from that, 62 percent of the total participants involved in the programmes were among women (ECERDC, 2019).

To date, studies on women's empowerment in Malaysia mainly focus on the roles played by the micro-finance institutions to eradicate poverty and empower women (Shuai, Shuai, Li and Huang, 2018). Most recently, Al Mamun, Ibrahim, Muniady, Ismail, Che Nawi and Md Nasir (2018) in their study examined the impact of access to working capital and micro-enterprise development training programmes on household income and economic vulnerability. Hence, this paper attempts to explore (1) the changes of income and occupation of the participants after joining these programmes, (2) socio-economic impacts of these programmes in improving the standard of living and (3) the overall impacts of these programmes in empowering the participants' lives. The next sections discussed the relevant literature and methods of the study, followed by findings and discussion of the study. Finally, the study highlighted the conclusion and policy recommendations at the last part of the paper.

\subsection{ECER Human Capital Development Programmes}

There are five human capital development programmes that are currently being implemented by ECER at rural areas of east coast region involving women.

Consisting of skills and entrepreneurship training, empower ECER adopts a rural community and development approach to reach disadvantaged adults such as the unemployed, underemployed, single mothers and aspiring youths. The adults were empowered with marketable skills to improve their job and business prospects.

entrepreneur ECER targets existing entrepreneurs in the region who wish to grow their business. The programme aims to increase the participation of Bumiputra entrepreneurs as well as 
entrepreneurs from other communities, including Orang Asli. entrepreneur ECER is implemented through collaboration with SIRIM and AGROBANK

The agropolitan project is a poverty eradication initiative based on the agriculture platform, under which hard-core poor participants are resettled and employed in agriculture plantation and the livestock industry. An integrated approach has been adopted with participants and their families moving into custom-built housing areas conducive for personal development and meaningful participation in the regional economy.

Suri@Home is a socio-economic development programme designed for women in ECER, especially housewives and single mothers with mobility constraints. Suri@Home encourages them to engage in home-based businesses such as tenun and songket weaving, as a means to help them earn regular additional income. Anchor companies have been appointed to provide training to the participants and market their products.

Terminal Jahitan is a tailoring outfit established in 2010 which is managed and operated by GIATMARA with start-up financial capital from ECERDC. It is located in Mersing, Johor and serves as a training centre that conducts apprenticeship courses to enhance employment opportunities among youths. ECERDC aimed to create new entrepreneurs among the trainees who graduated from Terminal Jahitan.

\section{LITERATURE REVIEW}

Literature review of the study refers to the references studies related to women's empowerment and socio-economic impacts of human capital development programmes on women.

According to Mahmud (2003), the relationship between socio-economic development and empowerment existed from development at the grassroots level. This study proved that there was a solid conceptual link to women's empowerment. Empowerment can be defined as an increase in power. Therefore, women's empowerment refers to women gaining control in various aspects of life. In the context of household, women's empowerment is about how women can contribute to the household income, opportunity in making decision and ownership of assets, equality in marriage, motherhood freedom and having rights for contraception and safe abortion (Parveen and Leonhauser, 2004). In other words, Banu, Farashuddin, Hossain, and Akter (2001) described women's empowerment as the capability of women to reduce the household socio-economic vulnerability and dependency on male, increase their involvement and control over household decisions, economic activities and resources, how they can contribute to household expenses, increase their self-confidence and social issue awareness. Women's empowerment is about having a right of entry to education, gender awareness and also freedom of movement (Cueva Beteta, 2006).

In a study on women's participation in microcredit programme by Hashemi, Schuler \& Riley (1996), they designed an 'empowerment index' in order to measure the impacts of microcredit on women's empowerment. A total of eight empowerment indicator were used, namely mobility, economic security, ability to make small purchases, ability to make larger purchases, involvement in major decisions, participation in public protests and political campaigning, relative freedom 
from family domination and political and legal awareness. Based on the analysis, they discovered a significant relationship between the contribution of women to their household income and women's empowerment. Apart from that, women felt that their status had improved within the household since they were part of income earners for their family. They also were seen to be more active in the household's decision-making and had more control over the household income, particularly on using the income derived from their own earnings.

Furthermore, the transformation in the areas such as access to employment, information and communication networks can mitigate regressive social norms only if they are able to penetrate domestic gender relations and not 'stop at the household doorstep' (World Bank, 2012). In this matter, education and training are one of the most important elements in empowering women as they will gain knowledge, skills and self-confidence that are vital for them to actively take part in the development process. In this study, women have been empowered by involving them in training courses on the road to becoming successful entrepreneur. According to Alam, Senik \& Jani (2012), the involvement and empowerment of women in entrepreneurship activities enable them to escape from the poverty trap and enhance the financial stability of the family, and later contribute to the nation's economy. In addition, women entrepreneurs help create vibrant economic activities especially in the domestic arena (Md Nor \& Ramli, 2016).

There are a number of studies that illustrate the roles of women entrepreneurs in eliminating poverty from different perspectives. In a study by Misango and Ongiti (2013) involving 100 women entrepreneurs in Kenya, they have been empowered by providing them opportunities to take part in economic activities such as promoting tourism, export-trading and selling African artifacts, clothing and ornaments. A longitudinal study conducted by Al-Dajani \& Marlow (2013) in discovering the relationship between women's empowerment and entrepreneurship found that women were empowered through their home-based enterprise. Through these income-earning activities, women not only can improve their position in the household but more than that, they can contribute to family welfare such as food and education of their children, as well as to the wider society (Mayoux, 2008). Undeniably, the empowerment of women through entrepreneurship is very impactful not only towards the socio-economic development of the household, but to prove their significant presence in the society. The increasing participation of women in economic activities will help reduce poverty particularly in rural areas that are less developed.

In a study conducted on the participants of development initiatives in Kelantan, Malaysia, which majority of the respondents are women shows positive impact of access to working capital and training programmes on household income and level of economic vulnerability (Wan Mustapa, $\mathrm{Al}$ Mamun \& Ibrahim, 2018). On the other hand, the women entrepreneurs in Salem District of Tamil Nadu have been empowered by providing them with adequate technical, financial and physiology supports. As a result, it improves their socio-economic status significantly (Sasikala, 2015). Rural women entrepreneurs in Selama District, Perak also contribute significant role in socio-economic development of local community by participating in small business. They are able to create their own career as entrepreneur, own an income and improving family financial condition (Mohd Saleh and Ahmad Razilan, 2016).

The women empowerment through social capital has a significant positive effect in enhancing socio-economic well-being of Malaysian local women. It improves business performance among low-income local women and gain access to information, knowledge, and professional advice 
(Ekpe, Mat, Mamun, and Nik Mahdi, 2015). Apart from that, a study by Yusof, Hassan, and P. Makol (2013) shows significant contribution of economic programmes in increasing rural women's income and provide financial support to improve their business performance. The programmes have lift up their quality of life and empower them with personal qualities such as skills and knowledge, confidence level and attitude. The aquaculture project in Nepal empowers women by equipping them with essential skills. Initial training and workshops increasing their self-confidence and enhancing their sense of community (Farquhar, Khanal, Shrestha, Farthing, and Bhujelet, 2018).

Additionally, skills training programme giving positive effect in improving socio-economic status of beneficiaries of microfinance in the Northern Region of Ghana. It enhances beneficiaries' ability to provide a better education for their dependence, improve their families' healthcare, acquire more household assets and enhance their empowerment (Alhassan and Goedegebuure, 2015)

This study has explored in detail the changes that happened towards the participants of Human Capital Development Programmes (HCDP) implemented by ECER, particularly towards their income and occupation before and after joining the programmes. Going further, this study scrutinizes the socio-economic impacts of the participants as it can be a proof on how these programmes empower women, particularly in rural areas of Kelantan, Terengganu, Pahang, and Mersing (Johor).

\section{METHODOLOGY}

The study used both primary and secondary data to achieve the objectives. The study used the quantitative method of research and issued a questionnaire to 147 respondents among empower ECER, entrepreneur ECER, Suri@Home, Agropolitan Project and Terminal Jahitan Programme in rural Kelantan, Terengganu, Pahang, and Mersing (Johor). A semi-structured questionnaire was administered to the participants. Majority of the respondents were participants of empower ECER (58\%), followed by entrepreneur ECER (16\%), agropolitan project (12\%), and Suri@Home programme (10\%). The remaining $4 \%$ of respondents were from Terminal Jahitan programme. $80 \%$ of the respondents are married while $12 \%$ of them are widow and divorcees. In the aspect of family members, most of the respondents $(58 \%)$ have a medium family which consists of five to eight members for each family. Concerning educational background, majority of the respondents finished their secondary school education whereby $54 \%$ of the respondents obtained Sijil Pelajaran Malaysia (SPM) qualification.

The first objective of this study measured by the income progress and occupation changes upon joining the HCDP. In the second objective, the socio-economic impacts measured by the participant's perception of how the project affects their life in terms of economic, social, and environment. The questionnaire designed on a positive scaling rate, in which 1 is the lowest rate and the highest is 5 . In measuring the third objective, the rating scale used to gain their satisfaction expression on the overall impact of the project in transforming their life, in which 1 is the lowest and the highest is 10 . Then, few open-ended questions used to gain their view pertaining to their experience upon joining the project, any problems or issues occurred, and their opinion about the project operator. Statistical Package for Social Science (SPSS) software has been used in this study to analyse the data. The descriptive analysis and Crosstab analysis used to answer the objectives. 
The study also uses a qualitative approach which includes in-depth interviews with ten key informants and a session of Focused Group Discussion (FGD) including direct observation. The informants comprised of 4 informants from the implementation level, and the remaining 6 informants were selected from the respondents involved in the questionnaire survey, in which 2 informants from Pahang state, 2 informants from Kelantan and one each in Terengganu state and District of Mersing. The FGD conducted with the project participants from Terminal Jahitan Programme. The in-depth interviews and FGD conducted in the participant's language. All the conversation recorded upon consent from the interviewees and participants of FGD. Later, the interviews and discussion translated and transcribed. Each interview session took between 40 minutes to one and a half hours. For the FGD, session took about one hour to two hours. Content analysis used to systematically evaluate the interview transcriptions. NVivo software used to analyse the qualitative data. A pilot study conducted with a total of 30 survey questionnaires distributed to test the reliability of the questions. Ethical approval sought before the actual survey conducted. Apart from that, the secondary data was collected from the reliable and dependable sources such as official government websites, ECER annual reports, statistics from published documents, and related journals and articles.

\section{RESULTS AND DISCUSSION}

Table 1: Occupation of the Participant Before and After Joining HCDP

\begin{tabular}{ccc}
\hline \hline & Occupation Before (\%) & Occupation After (\%) \\
\hline Government & 1 & 0 \\
Private & 5 & 19 \\
Self Employed & 65 & 80 \\
Jobless & 15 & 1 \\
Housewife & 14 & 0 \\
\hline \hline
\end{tabular}

Source: Abdul Latip (2019).

Table 1 shows the occupation of the respondents before and after participating in the Human Capital Development Programmes. Most of the respondents $(65 \%)$ were self-employed before joining these programmes, while $29 \%$ of the respondents were unemployed as they were doing nothing and became full-time housewives. On the other hand, 5\% of them were working in the private sector and there were $1 \%$ of the respondents working in the government sector before joining these programmes. Most of the self-employed respondents were running small business from home as they do not have capital to open a physical store. Many of them need to take care of their children and family at home but at the same time they are really passionate to increase their family's income and improve their standard of living. It can be seen that after joining these programmes, only $1 \%$ of the total respondents were jobless. Surprisingly, $12 \%$ of them were involved in the agropolitan project; a project dominated by men. The participation of women in workforce also increased by $28 \%$. Apparently, it has empowered them and their capability as women. 
Table 2: Income Progress

\begin{tabular}{cccccc}
\hline \hline Income (RM) & \multicolumn{7}{c}{} & \\
\hline Before & No & Percent (\%) & After & No & Percent (\%) \\
\hline 300 and below & 62 & 42 & 300 and below & 4 & 3 \\
$301-600$ & 27 & 18 & $301-600$ & 8 & 5 \\
$601-900$ & 5 & 3 & $601-900$ & 21 & 14 \\
$901-1200$ & 17 & 12 & $901-1200$ & 23 & 16 \\
$1201-1500$ & 12 & 8 & $1201-1500$ & 11 & 8 \\
$1501-1800$ & 1 & 1 & $1501-1800$ & 14 & 10 \\
$1801-2100$ & 4 & 3 & $1801-2100$ & 12 & 8 \\
$2101-2400$ & 0 & 0 & $2101-2400$ & 0 & 0 \\
$2401-2700$ & 1 & 1 & $2401-2700$ & 3 & 2 \\
$2701-3000$ & 6 & 4 & $2701-3000$ & 15 & 10 \\
3000 and above & 12 & 8 & 3000 and above & 36 & 24 \\
\hline Total & 147 & 100 & Total & 147 & 100 \\
\hline \hline
\end{tabular}

Source: Abdul Latip (2019).

Chart 1: Income Progress Before and After Joining The HCDP

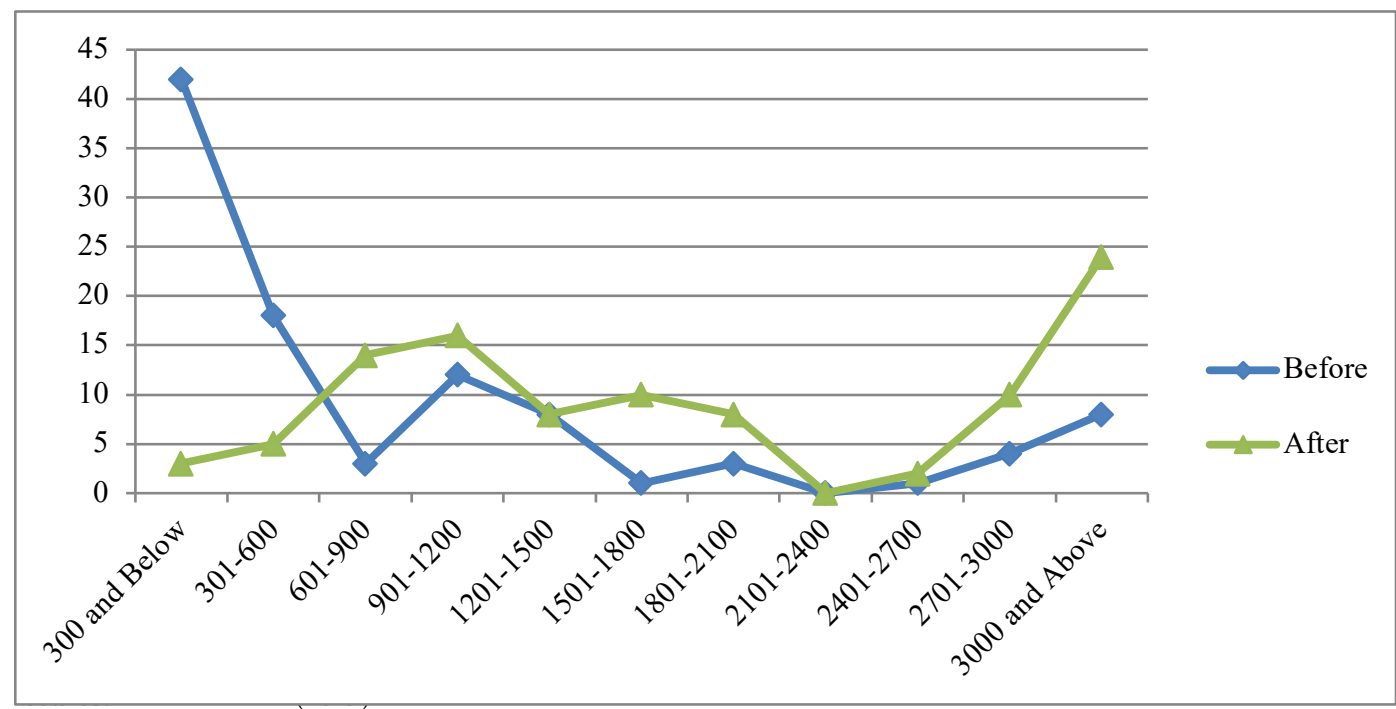

Source: Abdul Latip (2019).

Table 2 and Chart 1 reveal the monthly income of the respondents before and after participating in the HCDP. Majority of the respondents (42\%) earned a monthly income of RM 300 and below before joining these programmes. while $18 \%$ of them earned between RM 301 and 600 per month. After joining these programmes, only 3\% of the respondents earned less than RM 300 per month and only 5\% of them earned between RM 301 and 600 . As expected, the respondents with a monthly income of RM 601 and 900 increased by $11 \%$ and the top earners on a monthly income 
of RM 3000 and above increased their wages by $16 \%$. This figure indicates that in average, the incomes of the participants gradually increased after joining these programmes.

According to ECERDC (2017), empower and entrepreneur programmes have benefited more than 14000 participants, whereby $80 \%$ of the participants were women. Apart from that, $90 \%$ of them obtained a better job or became entrepreneurs after the course ended. These programmes managed to create about 11000 job opportunities.

Chart 2: Socio-economic Impacts Among Women

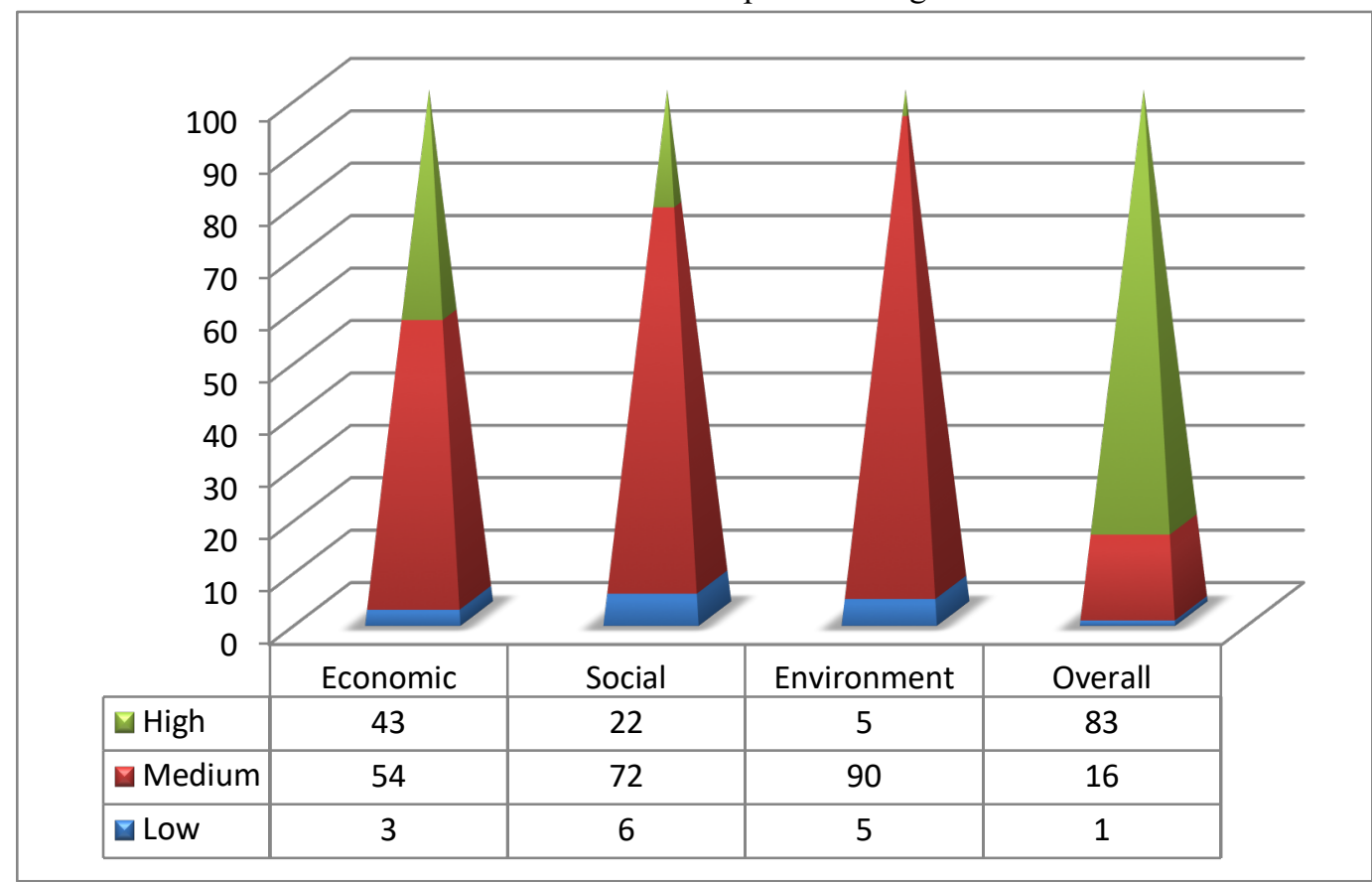

Source: Abdul Latip (2019).

Chart 2 represents the socio-economic impacts of human capital development programmes among women in ECER region. Women made up the majority of the participants in all the programmes implemented. Most of the programmes have been designed to empower and encourage the involvement of women in economic activities. As a result, women in this region were satisfied with the impacts of these programmes as they left positive changes in their socio-economic status.

$54 \%$ of the women expressed good feelings towards these programmes in regards to their economic conditions. They could actively be involved in helping their family earn an additional income. The programmes such as Suri@home and Terminal Jahitan managed to help single mother sustain their lives. The skills and knowledge acquired through these programmes became their assets to improve their well-being, as expressed by $72 \%$ of them. Earning an income can be done remotely and 
without compromising their day-to-day routines as housewives. The idea of working from home was very helpful and practical to ensure that they can take care of their children and family.

Overall, $83 \%$ of women in this region were highly satisfied and they could testify the impact these programmes have towards their lives. Initially, most of them participated in these programmes for leisure. Their involvement has proven to surprisingly transform their socio-economic status. Some of them have now become successful entrepreneurs. Through various skills and knowledge acquired from these programmes, these women can finally improve their standard of living and involve themselves in entrepreneurship activities which are the most relevant industry especially in rural areas of east coast region of Peninsular Malaysia.

Other than the training given to the participants, these programmes really empowered them with various soft skills and built their confidence to change for a better life. Based on the observation, most of the participants were highly motivated after joining these programmes and had a clear mission on what they should do in becoming a successful entrepreneur. They already explored their potential and discovered their capabilities. One of the strengths of empower programme is that the venue for training was located nearby the local community residential areas. It can be easily accessed and this programme was also held during weekends only. The attendance record was also very good as many of them really appreciated the effort taken by ECER. It was a free training programme provided for the local community within this region. As for Suri@Home Programme, the participants could earn a regular income through home-based activities. In Terengganu, the participants involved in Songket weaving were provided with complete weaving equipment by ECER and they just needed to do it from home. The programme included a guaranteed buy-back scheme by the participating anchor company.

One informant said:

..Most of the human capital development programmes are targeted to empower women in this region. Now, these programmes have evidently improved their socio-economic status. Suri@Home programme is specifically tailored for women. Majority of the participants of empower programme and Terminal Jahitan are women. Most of them are among single mothers and housewives. When we launch a programme, most of the participants are also mostly women...

(Respondent No. 1, Pahang)

One of the informants from empower ECER said:

...After only joining empower program, I have gathered strength to open for any booking. The confidence came after I learnt so many things during this programme. Prior to joining, I could bake only one type of cake but now I can do many. This programme gave me new knowledge. Not only that, now I made new friends and we love to share each other's experience. It made us more open minded and want to change for a better life. In a month, I earn about RM 900. It really helps our family as my husband is a farmer at a school and his salary is only RM 900 a month. Before joining this programme, I could earn only RM 50 in a week

I would say that this programme has improved our income and given a chance to a housewife like me to earn an additional income. This programme made me explore new business opportunities. Currently, I am trying to incorporate traditional cookies, such as 'Kuih Siput', as not many people include this variety in their businesses. Joining the programme has taught me to think outside the box and be creative 
The venue of the course was accessible and located nearby our residential area. It was easy for us to attend the classes. I had been looking for this course for such a long time. I could not afford to attend the private course as it was very expensive. Alhamdulillah, it was really helpful for villagers like us...

(Respondent No. 9, Terengganu)

One of the FGD participants said:

...Before joining this programme, I already had some basic sewing skills as I used to work at a factory. When I heard about this programme, I was very interested to join as I love sewing. This programme has taught me everything from cutting and sewing until I managed to make a shirt. Everyone must complete the course. This programme really opened our mind to think and act as an entrepreneur...

(Participant No. 3, Mersing)

Despite its achievement, there are a few barriers of these programmes that hinder the achievement of its ultimate goals.

- Transparency in the selection of participants: There were some participants that should not be listed in these programmes. Although the programmes aimed to reach the families in real poverty, there was a government worker and a number of participants joining this project whose monthly income is more than RM 1500 per month. They were happy to be selected as the programmes provided them with free training classes.

- Criteria in the selection of participants: The highly passionate candidates who want to start a business must meet the top criteria to be selected for this programme. Some of the participants did not pursue business even after the course ended. The reason given was that they joined these programmes to fill in their free time and they did not have any intention in starting a business.

- The assistance after courses ended. Some of the participants cannot afford to start a business after the course ended as they come from a poor family. ECER will only provide assistance once they have shown good progress in their business. Prior to that, the participants themselves must find their own initiatives on how to start their business activities.

\section{CONCLUSION}

This paper has highlighted the increasing participation of rural women in the workforce through the human capital development programmes implemented by ECER. The participants' income has significantly increased after joining these programmes. Other than that, this study has discovered the socio-economic impacts of the ECER human capital development programmes on the women in the rural areas of Kelantan, Terengganu, Pahang, and Mersing (Johor) which are largely positive. The participants' lives have transformed after joining these programmes especially in reducing the poverty issue and improving social well-being and lifestyle.

In contrast, there are also several issues related to the participants that require attention from the implementing agencies. ECER and project operator should give attention on the sustainability of 
these programmes. The survival of the participants in entrepreneurship after the completion of the programme should be considered. A proper planning and support group can help the participants to sustain their entrepreneurship activities. Government can also make use of the findings of this study in the monitoring and evaluation of the development programmes that are implemented by ECER in the region. Later, it can be valuable inputs for future development planning process in empowering rural women.

Based on the discussion, the ECER human capital development programmes are on track in empowering rural women within the region. With regard to the impacts on rural women, more studies should be conducted on other aspects of women's empowerment index. In the future, women could become significant contributors in improving the socio-economic development of this region.

\section{REFERENCES}

Abdul Latip, A. R. (2019). Impact Evaluation of the East Coast Economic Region (ECER) Development Programmes in Improving the Socio-economic Status of the Local Community (Unpublished doctoral dissertation). Universiti Sains Malaysia, Malaysia

Al-Dajani, H., \& Marlow, S. (2013). Empowerment and entrepreneurship: A theoretical framework. International Journal of Entrepreneurial Behavior \& Research, 19(5), 503524. doi: 10.1108/ijebr-10-2011-0138

Alam, S., Senik, Z., \& Jani, F. (2012). An exploratory study of women entrepreneurs in Malaysia: Motivation and problems. Journal of Management Research,4(4). doi 10.5296/jmr.v4i4.2377

Alhassan, A. I., \& Goedegebuure, R. (2015). The value of skills training in the improvement of the socio-economic status of microfinance beneficiaries: A case study at Grameen Ghana. Special Issue- UMM Master Awards 2015.

Al Mamun, A., Ibrahim, M. A. H., Muniady, R., Ismail, M., Che Nawi, N., \& Md Nasir. N. A. (2018). Development programmes, household income and economic vulnerability. World Journal of Entrepreneurship, Management and Sustainable Development, 14(4), 353-366. doi: 10.1108/wjemsd-01-2018-0008

Banu, D., Farashuddin, F., Hossain, A., \& Akter, S. (2001). Empowering women in rural Bangladesh: Impact of Bangladesh Rural Advancement Committee's (BRAC's) Programme. Journal of International Women's Studies, 2(3), 30-53. doi: https://vc.bridgew.edu/jiws/vol2/iss $3 / 3$

Cueva Beteta, H. (2006). What is missing in measures of women's Empowerment?. Journal of Human Development, 7(2), 221-241. doi: 10.1080/14649880600768553

ECERDC. (2019). ECER Master Plan 2.0 the Next Leap 2018-2025. Kuala Lumpur: East Coast Economic Region Development Council

ECERDC. (2017). East Coast Economic Region Development Council Annual Report 2016. Kuala Lumpur: East Coast Economic Region Development Council

Ekpe, I., Mat, N., Mamun, A., \& Nik Mahdi, N. M (2015). Enhancing the socio-economic wellbeing of Malaysian local women through social capital and micro-enterprise performance. Journal of Entrepreneurship and Business, 3(2), 13-25. 
The Star Online. (2018). Empowering Malaysian women-nation. Retrieved from https://www.thestar.com.my/news/nation/2018/05/02/empowering-malaysianwomen/\#KYZcY2RB2wgQ4oJa.99

Farquhar, S., Khanal, N., Shrestha, M., Farthing, M. and Bhujel, R. (2018). Socio-economic impacts of the Women in Aquaculture (WiA) project in Nepal. Kasetsart Journal of Social Sciences.

Hashemi, S., Schuler, S., \& Riley, A. (1996). Rural credit programmes and women's empowerment in Bangladesh. World Development, 24(4), 635-653. doi: $10.1016 / 0305-750 x(95) 00159-a$

Mahmud S. (2003). Actually how empowering is microcredit? Development and Change, 34(4), 577-605

Mayoux, L. (2008). Taking gender seriously: Towards a gender justice protocol for financial services. Retrieved from http://citeseerx.ist.psu.edu/viewdoc/download? doi $=10.1 \cdot 1.508 .7979 \& r e p=$ rep $1 \&$ type $=p \quad$ df

Md Nor, Z., \& Ramli, Z. (2016). A glimpse at women entrepreneurs in Penang. Akademika, 86(02). doi: 10.17576/akad-2016-8602-06

Misango, S., \& Ongiti, O. (2013). Do women entrepreneurs play a role in reducing poverty? $A$ case in Kenya. Retrieved from https:/www.researchgate.net/publication/ 282855026_Do_Women_Entrepreneurs_Play_a_Role_in_Reducing_Poverty_A_Case_ in_Kenya

Mohd Saleh, R., \& Ahmad Razilan, R. (2016). The role of women in rural socio-economic development in Selama District, Perak. International Journal of Accounting and Business Management, 4(1), 37-49.

Parveen, S., \& Leonhäuser, I. (2004). Empowerment of rural women in Bangladesh: Ahousehold level analysis. Retrieved from http://www.tropentag.de/2004/abstracts/ full/382.pdf

Sasikala, T. (2015). The socio-economic status of women entrepreneurs in Salem district of Tamil Nadu. HuSS: International Journal of Research in Humanities and Social Sciences, 2(1), 40.

Shuai, Y., Shuai, C., Li, W., \& Huang, F. (2018). Role of women's empowerment in improving farmer's livelihood: Empirical evidence from China. Quality \& Quantity. doi: 10.1007/s11135-018-0778-6

Wan Mustapa, W. N., Al Mamun, A., \& Ibrahim, M. D. (2018). Economic impact of development initiatives on low-income households in Kelantan. Malaysia. Social Sciences, 7(7), 118.

World Bank. (2012). World Development Report 2012: Gender equality and development. Washington, DC: World Bank.

Yusof, R., Hassan, K., \& P. Makol, B. (2013). The impacts of socio-economic activities towards improving the quality of life among rural women. Journal of Governance and Development, 9, 93-116. 